\title{
The Russo-Chinese Strategic Partnership: Oil and Gas Dimensions
}

\author{
Jean-Marie Holtzinger *
}

\begin{abstract}
This essay seeks to determine the nature of the strategic energy partnership between the Russian Federation and the People's Republic of China, focusing on oil and gas. In particular, it will attempt to answer the question of whether there is a real and valid strategic energy partnership between the two countries. Many joint declarations, statements, and treaties on the strategic partnership have offered evidence of the good relationship between the two countries. These have been reinforced in recent years through cooperation in different fields - economy, military, and energy-underpinned by an apparently common shared vision of the world. As far as the energy partnership is concerned, many advances have been achieved in the oil and gas sectors. This results from a complementary association of both actors that gives priority to market forces, since Russia is a major oil and gas producer and China, because of its growing economy, is a major consumer. However, this strategic energy partnership is limited in scope, and is very fragile for many reasons: the Russian domestic market is growing; Europe is a more attractive partner for Russian energy exports; Russia has fears regarding China's rapid expansion in economic and geopolitical power; China's tendency to engage in active diplomacy in all directions; and the influence of Japan and South Korea on the Asian market. All factors indicate that there is at present an energy partnership between the two countries, but that it seems to be more strategic for Russia than for China.
\end{abstract}

\section{Introduction}

After the collapse of the Soviet Union, China and Russia tried to improve their relationship and to resolve their past issues of contention. Relations between both countries may be described as successful, and in various fields cooperation between Moscow and Beijing has even been enhanced. China and Russia came to an agreement in July 2008 to end a decades-long border dispute. Thus, the delineation of the RussianChinese border has been accepted by the two partners, and is no longer an issue. ${ }^{1}$

China and Russia communicate and act through bilateral consultations as well as within the framework of the Shanghai Cooperation Organization (SCO), sharing the same principles and visions, such as the right to sovereignty or territorial integrity. Beyond these shared political and philosophical views, China and Russia have experienced different paths of economic development since the 1990s. Russia has faced many difficulties in changing its economic system and adapting to the liberal market. Furthermore, the Russian government is aware that the country's economic develop-

Major Holtzinger is a specialist in International Relations. Focusing on Eastern Civilizations and particularly on China, he followed the $24^{\text {th }}$ international training course at the Geneva Centre for Security Policy. He is currently an English professor at the French Military Academy of Saint-Cyr.

1 “China, Russia End Lengthy Border Dispute," Moscow News 41 (16 October 2008); available at www.moscownews.ru/national/20081016/55351138.html. 
ment is the principal method that will help restore its status as a great power. To reach this goal, Russia relies on its two main supports: the military-technology industry and the energy sector. The energy sector provides the bulk of the government's revenues and, provides Moscow with a powerful tool of influence, since Russia is a major global producer and provider of oil and, above all, natural gas. China is in a quite different position; the rapidity of its economic growth has been astounding to many analysts. China has become both a major producer and investor, and has also emerged as the banker of the world (this is in addition to the potential offered by its huge domestic market). The Chinese have produced a semi-liberal economy that has been able to adapt efficiently to the processes of globalization. In addition, China has not suffered significantly from the recent global financial and economic crisis, which has reinforced its position as a global actor.

China's demand for energy has risen and will continue to increase. If it wants to sustain its growth, China needs an effective energy policy. Thus, the cooperative relationship between China and Russia has been logically extended to the energy sector, and particularly to the areas of oil and gas. Russia is willing to sell oil and gas to China, and China needs to buy oil and gas from Russia. This apparently pure market exchange hides a more conceptual strategic energy partnership between the two countries, which is in turn rooted in a more complex game of influences. The strategic partnership can be defined as an alignment of compatible interests or approaches, a converging perception of the world enhanced by strong bilateral ties in several domains.

In 2008, the noted Russia expert Bobo Lo argued that Russia and China's understanding of the strategic partnership differ. The partnership with China is strategic for Russia, since it provides an alternative to Russian foreign policy, but especially because it constitutes a guarantee against a powerful and "potentially aggressive China." 2 In other words, the partnership with China enables Russia to have flexibility among strategic orientations, and simultaneously allows for proactive prevention. China, unofficially, does not aspire to build a so-called strategic partnership, but is rather trying a realistic approach that serves its national interests. This approach is limited in scope to the economy. The strategic partnership, for both countries, serves common interests, but to different ends. At the moment, these interests are compatible, but they may become incompatible, given the possibility that their trends will diverge in the long run. Is this strategic partnership an empty vessel? What is the real purpose of the strategic oil and gas partnership? This article will demonstrate that - more than two years after Bobo Lo's statement - if the energy partnership appears to be strategic for Russia, it is not the case for China, which considers Russia as one provider of oil and gas among others, and does not want to increase its dependence on Moscow beyond what is economically necessary.

2 Bobo Lo, Axis of Convenience: Moscow, Beijing, and the New Geopolitics (Washington, D.C.: Brookings Institution Press, 2008), 44. 


\section{Energy as the Central Factor in Economic Relations}

Economic ties have been strengthened between China and Russia over the last decades. Russian arms sales to China have for a long time accounted for a major part of Russia's arms exports - often around 40 percent of total sales, and even reaching 60 percent in some years. This trade relationship has to be considered as a major one between the two countries. However, other areas of economic cooperation have been developed, especially in the energy sector. Russia exports its electricity to China at a price higher than Russia's domestic regulated tariffs. Its two main electricity exporting plants, Bureiskaya and Zeiskaya, are located in the Far East. In 2007, Chinese officials argued that the price they paid for Russian electricity was too high, and negotiated for a better price. Russian electricity exports resumed in 2009. ${ }^{3}$ Nuclear cooperation with China started in 1990, and since then different agreements have been signed. Using Russian nuclear power equipment and support from Russia's service export monopoly, Atomstroyexport, China built two new generation reactors in the Tianwan Nuclear Plant near Shanghai. The second reactor became fully operational in $2007 .{ }^{4}$ The proportion of energy in China that is produced by nuclear plants is growing, but still marginal. In 2009, eight new power plants were under construction, and another eight are in the planning stages. However, three-quarters of China's electricity is produced from coal, and this trend will continue until 2030. The development of gas-fired power plants stands as a governmental priority. ${ }^{5}$

Focusing more specifically on oil and gas, there are several significant collaborative projects between China and Russia that are worthy of mention. In November 2006, the Open Joint Stock Company Rosneft of Russia and the China National Petroleum Corporation (CNPC) set up a joint venture in China focusing on oil exploration and production in Russia. In addition, thirteen deals were signed to encourage investment, promote Russian machinery exports and technical products, and enhance cooperation between oil companies. ${ }^{6}$ Even since October 2009, many new contracts have been signed. Gazprom reached a framework agreement with CNPC on gas delivery, while Rosneft will continue its cooperation with this same company. In 2010, an oil refinery is supposed to be built in Tiantsizin with a capacity of 200,000 barrels a day. In Vladivostok, in partnership with the Sino-Singaporean company Yantai, huge shipyards will

Sergei Blagov, "Russia Resumes Electricity Exports to China," Eurasia Daily Monitor 6:65 (6 April 2009); available at http://www.jamestown.org/single/?no_cache=1\&tx_ttnews\%5 Btt_news\%5D=34817.

4 International Atomic Energy Agency, "Power Reactor Information System" (2010); available at www.iaea.org/programmes/a2/.

5 U.S. Energy Information Administration, "Country Analysis Brief: China" (July 2009); available at www.eia.doe.gov/emeu/cabs/China/Electricity.html.

6 Guo Qiang, "Russia, China Cement Oil Cooperation," Chinadaily.com.cn (13 November 2006); available at www.chinadaily.com.cn/china/2006-11/13/content_731888.htm. 
be built for the production of oil rigs. ${ }^{7}$ Moscow seems to place priority on huge transnational projects in order to develop energy resources in Eastern Siberia and the Russian Far East, such as the Eastern Siberia-Pacific Ocean (ESPO) oil pipeline and the Russian-Chinese branch of the oil pipeline from the Skovorodino refinery, in the Amur region, to Mohe county in China's Heilongiiang province. Since there is a lack of qualified Russian workers in these Eastern regions, it was necessary to call for workers from other regions to build the pipeline. In the summer of 2007, Transneft wanted to employ 1,500 Chinese workers for this purpose. ${ }^{8}$ In the context of the global economic crisis, financial help from China is welcomed by Russia. In 2009, the Chinese Bank for Development granted a USD ten billion credit to Transneft, and USD fifteen billion to Rosneft. A contract between Transneft and the CNPC outlines the laying and the exploitation of the oil pipeline to China, which should be completed by the end of 2010. A contract signed by Rosneft and the CNPC calls for the annual delivery of fifteen million tonnes of oil to China for twenty years. ${ }^{9}$ At the same time, both countries signed a framework agreement aiming to increase Chinese imports of Russian gas and enhancing cooperation between the main energy companies. In October 2009, Russia agreed to deliver approximately sixty-eight billion cubic meters of gas to China. Two delivery routes were determined: the eastern one, from Eastern Siberia, the Russian Far East, and the Sakhalin continental shelf, and the western one from the Western Siberian gas fields. ${ }^{10}$

All this development is natural because of the common interests of both Russia and China. Moreover, they are driven primarily by business market forces, thus creating a complementary association.

\section{A Complementary Association}

Russia is a major producer of oil and gas, while China is a major consumer. The geographical proximity of the two countries and their shared interest in the energy sector logically create a complementary association driven by market forces and need. Russia has more proven natural gas reserves than any other country, is among the top fifteen in proven oil reserves; it is the world's largest exporter of natural gas, the second-largest oil exporter, and the third-largest energy consumer. Energy exports have been crucial for Russia's economic growth over the last five years, during which period Russian oil production has increased considerably and world oil prices have peaked. According

7 Philippe Randrianarimanana, "Good Weather on Economic Cooperation," Courrier International (27 November 2009); French version (published 14 October 2009) available at www.courrierinternational.com/revue-de-presse/2009/10/14/beau-temps-sur-la-cooperationeconomique.

8 Sabrina Vidalenc, "Russian Far East: A New Frontier?" (September 2009); available at www.ceri-sciences-po.org.

9 Elena Mazneva, "Neft na 20 let vpered," Vedomosti 29 (2299) (18 February 2009); available at www.vedomosti.ru/newspaper/article.shtml?2009/02/18/182314.

10 "Russia, China Agree on West Siberia, Far East Gas Supplies," RIA Novosti (13 October 2009); available at http://en.rian.ru/business/20091013/156450825.html. 
to the Oil and Gas Journal's 2008 survey, Russia has proven oil reserves of sixty billion barrels, mainly located in Western Siberia, between the Ural Mountains and the Central Siberian Plateau. Eastern Siberia is starting to be developed as well.

In 2008, Russia was the world's leading oil producer, with 9.4 million barrels per day, even surpassing Saudi Arabia. However, 50 percent of Russia's largest oil fields are almost depleted, and no more oil fields remain to be discovered. ${ }^{11}$ This means that at the current rate the Russian Federation will able to produce oil for the next twentytwo years, ${ }^{12}$ which seems like an unimpressive figure, but is actually much greater than other producers. In 2008, Russia consumed 130.4 million tonnes of oil, and was in the top five of the global oil consumers. ${ }^{13}$ Russia exports its oil mainly to the European market, in addition to the United States and Asia. Most of Russia's oil is transported by pipelines, as well by sea and rail. So far, Russia has supplied China's oil shipments by train. Its pipeline network is dated, with some infrastructure dating from the Soviet era. Hence, huge investments are necessary to increase or at least to maintain the current level of production. Russian oil is heavily taxed by the Russian government, because it is very profitable. But this tax system and the lack of government flexibility may dissuade foreign investors from providing the funding necessary to develop the oil sector. There is a double system of taxes, without any domestic harmonization, since the federal government uses tax breaks to try to promote production in the East Siberian oil fields, and the Taman-Pechora (Far North). Since the Western Siberian and the older oil producing regions do not receive these same incentives, they are effectively taxed twice. This unfair tax structure is a problem for smaller companies, and limits their development. $^{14}$

The gas sector offers more opportunities for Russia. It has the largest reserves of natural gas in the world, representing 23.4 percent of total verified gas deposits, with 43.30 trillion cubic meters in 2008 , which is the equivalent of seventy-two years of possible exploitation. ${ }^{15}$ Russia is also the world's most important gas producer; it represents 19.6 percent of total production, with almost 602 billion cubic meters in 2008. ${ }^{16}$ The main portion of this resource (approximately 70 percent) is consumed domestically within Russia. The remaining production is dedicated to exports destined for Europe and Turkey. ${ }^{17}$ An interdependent relationship has been developed with Europe,

11 U.S: Energy Information Administration, "Russia Independent Statistics and Analysis" (May 2008); available at www.eia.doe.gov/emeu/cabs/Russia/Oil.html.

12 BP Statistical Review of World Energy 2009; available at http://www.bp.com/liveassets/ bp_internet/globalbp/globalbp_uk_english/reports_and_publications/statistical_energy_review

13 Ibid. 2008/STAGING/local_assets/2009_downloads/oil_table_proved_oil_reserves_2009.pdf.

14 Alex Burgansky, "Russian Oil and Gas Industry Surprises Analysts," Seeking Alpha (25 September 2009); available at http://seekingalpha.com/article/163358-alex-burgansky-russianoil-and-gas-industry-surprises-analysts.

15 BP Statistical Review of World Energy 2009.

16 Ibid.

17 Ibid. 
since Russia can sell its gas to European markets at a high price and at the same time needs the Euros to develop the country in general, and especially the energy sector.

As is the case with oil, the majority of Russian gas is transported via pipelines running in and out of the country. The domestic gas distribution network is aging, and much of the infrastructure requires heavy maintenance operations. On 30 July 2007, after an explosion of a gas pipeline that occurred near St. Petersburg, an official inspection conducted by the Federal Service for Ecological, Technological, and Atomic Oversight, came to the conclusion that a great number of Gazprom's production and pipeline subsidiaries were not safe. ${ }^{18}$ Russia also relies on maritime transportation, and has worked to develop its own port facilities, terminals, and tanker fleets. The use of this infrastructure depends heavily on climate and geographical constraints, which may reduce Russia's shipping capacity. However, this mode of transportation is going to be increasingly important with the development of liquefied natural gas (LNG) in Russian energy production. ${ }^{19}$ Gas is also transported by rail and river, but these types of transportation are decreasing in importance, especially to the Western markets. ${ }^{20}$

In recent years, the level of the Russian government's control over Russia's oil and gas industries has increased considerably. The energy doctrine elaborated by Vladimir Putin in 2003 stated that the role of Russia in global energy markets would significantly determine its geopolitical influence. From this point of view, the oil and gas sectors have served effectively as instruments of Russian domestic and external policy. ${ }^{21}$ President Putin reestablished the state's primacy over Russian oil and gas firms. He took control of the main Russian energy firms by imposing new leadership and strategies. ${ }^{22}$ The dismantling of Yukon and the formation of major groups such as Gazprom, Rosneft, and Transneft showed that the state's will was to indirectly take control over these companies. Russian energy firms are not officially nationalized, but the state holds a majority ownership stake. There have been tensions between the Russian government and foreign groups over the exploitation of oil and gas fields. In December 2006, after negotiations with Russian Energy Minister Viktor Khristenko, the DutchBritish company Shell accepted an offer (which was more of a demand) to sell to Gazprom half-plus-one of its shares of a company that was exploiting a gas field in Sakha-

18 Sergei Blagov, "Russia's Gas Pipeline Network Faces Reality Check," Eurasia Daily Monitor 4:150 (1 August 2007); available at www.jamestown.org/single/?no_cache=1\&tx_ttnews $\% 5 \mathrm{Btt}$ news $\% 5 \mathrm{D}=32916$.

19 John Margeson, "Russia: Survey of Russian Energy Infrastructure," International Analyst Network website (25 January 2008); available at www.analyst-network.com/article.php? art_id=1634.

${ }^{20}$ Ibic.

21 Pierre Verluise, "How the EU Reinforces Russia’s Power," diploweb.com (November 2006); available at www.diploweb.com/forum/verluise06113.htm.

22 Steven Woehrel, Russian Energy Policy toward Neighboring Countries, CRS Report RL 34261 (Washington, D.C.: Congressional Research Service, 2 September 2009); available at http://opencrs.com/document/RL34261/. 
lin II. ${ }^{23}$ Today, Gazprom is the top gas company in the world, but Russia's aggressive attitude towards foreign investors may eventually become counterproductive.

China is in a completely different situation from Russia as far as energy consumption and production are concerned. First of all, China's consumption and production of coal remains very high. Coal represents 70 percent of China's total primary energy consumption. ${ }^{24}$ Despite its large coal reserves - approximately 13 percent of the world's total, the third-largest behind the United States and Russia - China may within five to ten years become a net coal importer to supply the growing demand from its industrial sector, and because coal prices are going to be more attractive on the global market. ${ }^{25}$

China's production of oil increased by 1.4 percent in 2008, to 3,795 thousand barrels a day, representing 4.8 percent of overall global production. China was then the fifth-largest oil producer in the world. In the same year, however, China consumed 7,999 thousand barrels daily, around 9.6 percent of total global consumption, making China the second-largest oil consumer in the world, after the United States. ${ }^{26}$ In 1998, China consumed 4,228 thousand barrels a day, ${ }^{27}$ which means that in ten years Chinese oil consumption had nearly doubled. By 2030, the demand for oil for transportation will have multiplied four-fold, ${ }^{28}$ which will considerably increase China's dependence on foreign oil. The Chinese oil industry is dominated by three major companies: the CNPC, the China Petroleum and Chemical Company (Sinopec Group), and the China National Offshore Company (CNOOC). These companies, which are officially state firms, are listed on the Chinese stock exchange; they represent the overwhelming majority of China's oil output. ${ }^{29}$

Along with oil, China also produces and consumes natural gas. In 2006, natural gas accounted for 3 percent of the country's total energy consumption. ${ }^{30}$ In 2007, for the first time, China became a net natural gas importer. And its consumption will grow quickly; current estimates hold that natural gas consumption in China will triple by $2030 .^{31}$ According to BP statistics in 2008, China is the world's ninth-largest natural gas producer. China's production more than doubled between 2005 and 2008. In 2008, China was the sixth-largest natural gas consumer in the world, after the United States, Russia, Canada, the United Kingdom, and Iran. ${ }^{32}$

23 Alain Guillemoles, "Gazprom, a Giant for the Benefit of Kremlin," Politique Internationale 116 (Summer 2007).

24 U.S. Energy Information Administration, "China: Coal" (July 2009); available at www.eia.doe.gov/emeu/cabs/China/Coal.html

25 Ibid.

26 BP Statistical Review of World Energy 2009.

27 Ibid.

28 Alexandre Panizzo, “China's Oil Thirst," Le Figaro (3 January 2008).

29 U.S. Energy Information Administration, "China: Oil”" (July 2009); available at www.eia.doe.gov/ emeu/cabs/China/Oil.html

30 U.S. Energy Information Administration, "China: Natural Gas" (July 2009); available at www.eia.doe.gov/emeu/cabs/China/NaturalGas.html.

31 Ibid.

32 BP Statistical Review of World Energy 2009. 
Until recently, the natural gas infrastructure in China was not very developed, essentially because the demand was low. With increasing consumption, the Chinese authorities have launched a new project of regional pipelines linked with international networks of pipelines. ${ }^{33}$ One major international project has been completed. The West-East pipeline from Tajikistan to China, also known as the Central Asia China gas pipeline (CAC), became operational at the end of December 2009.

In 2006, China started to import LNG, but the evolution of the sector has been so far limited, since the price paid by China for LNG remains very high. In Asia, China is in direct competition with Korea and Japan, who are willing to buy LNG at any price. ${ }^{34}$ China will depend more heavily in the future on gas and oil imports to meet growing demand and to fill the gap between its domestic production and consumption. The Chinese government decided to increase its imports of both natural gas and LNG in order to diversify its imports not to be dependent on a single actor, such as Russia.

\section{Limitations of the Energy Partnership}

There are several obstacles that may impede the progress of the strategic energy partnership between China and Russia. First, Russia's domestic consumption of gas is very high, around 420 billion cubic meters in 2008 (13.9 percent of global gas consumption). This consumption has grown considerably - in 2000, Russian gas consumption was 366 billion cubic meters ${ }^{35}$ - and it will only increase in the future. The level of consumption is so high because Russia maintains artificially low gas prices in the domestic market. Russia uses its gas mainly for power generation, for industry, and for households. On the one hand, these low prices are an important tool for the government to ease internal social pressure from citizens; ${ }^{36}$ on the other hand, Gazprom does not make any domestic profits, and the government loses money. This means that Russia, even if its natural gas resources were sufficient, will not be able to increase the delivery of gas to new customers (or China) unless new gas fields are discovered or domestic consumption decreases. However, there is no urgent official willingness to change the system, since Russia's earnings from gas exports remain comfortable. Russia has announced that it plans to increase natural gas and electricity prices by 2011 , but it remains to be seen how the Russian populace will respond. ${ }^{37}$

Second, the European market seems to be more attractive than the Chinese one. Since the sixth EU-Russia Summit, held in Paris in October 2000, Russia and the EU have developed a strong partnership underlining their "strong mutual dependency and

33 Nobuyuki Higashi, "Natural Gas in China: Market Evolution and Strategy International Energy Agency," Working Paper Series (June 2009), 7.

34 Catherine Locatelli and Jean-Pierre Angelier, "What Development for Gas in China," Laboratoire d'économie de la production et de l'intégration internationale (February 2007), 4; available at http://upmf-grenoble.fr/iepe/textes/CL-JPA_Energies-2007.pdf.

35 BP Statistical Review of World Energy 2009.

36 Woehrel, "Russian Energy Policy toward Neighboring Countries."

37 U.S. Energy Information Administration, "Russia: Natural Gas," (May 2008); available at www.eia.doe.gov/emeu/cabs/Russia/NaturalGas.html. 
common interest in the energy sector." An Energy Dialogue has been developed since then, based on several working levels. ${ }^{38}$ Over the last ten years, Russia has been a trustworthy partner for the EU, and never stopped its energy supply to Europe, even during the different energy crises that occurred (including during the last one with Ukraine, in January 2009). An early warning mechanism to prevent any major disruption of supplies was agreed upon by the EU and Russia on 16 November 2009. ${ }^{39}$ The European market is an extremely lucrative market, especially in comparison with the Chinese one; prices in Europe are very high, around USD 370 per thousand cubic meters in $2008 .^{40}$ Europe is currently the major partner for Russia as far as oil and gas exports are concerned.

In addition, several new projects are under development, such as the "South Stream" and "Nord Stream" pipelines. The former was agreed upon in 2007, and involves a partnership between Russia and the Italian firm Eni. This pipeline, which should be completed in 2015, will transport gas from the Beregovaya compressor station in Russia through the Black Sea to Bulgaria and further to Austria and Italy. The "Nord Stream" pipeline should transport gas from Vyborg in Russia to Greifswald in Germany, under the Baltic Sea. It should be completed in 2012, and is aimed at bypassing the countries in Central and Eastern Europe, mainly for political reasons. ${ }^{41}$ Most of the infrastructure is located in the western part of Russia and is linked with Europe. This infrastructure is much more substantial than that which currently exists in the eastern part of Russia. It is therefore more profitable to use the already existing infrastructure than to build new expensive pipelines towards the Asia-Pacific region, even though it is explicitly stated in the "New Energy Strategy of Russia to 2030" that one of the nation's main objectives is to develop new oil- and gas-bearing provinces in Eastern Siberia and in the Far East. ${ }^{42}$ The development of the eastern part of the country will remain a priority for the Russian Federation, but it will require massive investments. Furthermore, Russia wants to improve and develop an integrated system to bring resources from the oil and gas fields to consumers including refineries, transport systems, reserve capacity, and gas processing and petrochemical plants. These investments may dissuade China from investing too massively in big projects as long as it is looking for the cheapest prices for gas and oil.

38 “EU-Russia Energy Dialogue," European Commission Energy Website (19 March 2009); available at $\mathrm{http}$ //europa.eu/rapid/pressReleasesAction.do?reference=MEMO/09/121\&format= HTML\&language $=$ en.

39 "The EU and Russia Reinforce the Early Warning Mechanism to Improve Prevention and Management in Case of an Energy Crisis," European Commission Energy Website (16 November 2009); available at http://europa.eu/rapid/pressReleasesAction.do?reference=IP/09/ $1718 \&$ language $=$ en.

40 U.S. Energy Information Administration, "Russia: Natural Gas."

41 Woehrel, "Russian Energy Policy toward Neighboring Countries."

42 Andrey Korzhubayev, "Hydrocarbon Arteries of Russia," Oil of Russia 2 (2009); available at www.oilru.com/or/39/787/. 
Third, China has attempted so far to remain independent from Russian oil and gas, despite its geographical proximity to Russia. China would not like Russia to use its energy resources as leverage. Even if China were to increase its dependence on Russia through the energy partnership, it will nonetheless work through a set of actors that will preserve Chinese freedom of action. China has developed a clearly articulated energy policy based on the diversification of imports. The three main Chinese companiesChina National Petroleum Corporation, China National Petrochemical Corporation, and China National Offshore Oil Cooperation - buy foreign gas and oil fields in order to control them directly and conclude direct agreements with neighboring countries on the construction of new pipelines to transport oil and gas directly to China. China's growing thirst for energy resources has pushed it to use all possible diplomatic means with countries in different regions of the world. Apart from Russia, relationships have been developed with partners in the Persian Gulf, Central Asia, Africa, Latin America, and Canada. China has negotiated with Libya, Saudi Arabia, and Syria to secure 60 percent of the oil coming to the PRC from the Middle East. ${ }^{43}$

Fourth, in different regions of the world China and Russia seem to be more competitors than partners, which may have negative implications for their energy partnership. The opening of the Central Asia-China gas pipeline may not be a cause of particular delight in Moscow, as it seems to be yet another symptom of Russia's loss of influence in this region. This pipeline transports gas from Turkmenistan to China through Uzbekistan and Kazakhstan. Prior to the inauguration of this pipeline, almost 70 percent of Turkmen natural gas production "used to exit the country through the Gazprom network." 44 The pipeline to China strengthens China's position in its negotiations with Moscow on gas prices. China and Russia have not yet concluded their negotiations on the price China should pay for Russian exports from Eastern Siberia to China. Now, the new pipeline appears to be a direct competitor to the Russian-Chinese one, and China will take into account the Turkmen gas prices in its future negotiations with Russia. ${ }^{45}$ In Latin America, Russia has developed economic relations based mainly on arms sales, commercial contracts, and energy and military cooperation with Brazil, Venezuela, Cuba, and Nicaragua. ${ }^{46}$ At the same time, Cuba sells nickel to China, Venezuela exports oil to China, Brazil provides iron and soy to China, while Nicaragua wishes to improve its economic cooperation with China. Russia has suffered greatly from the international financial crisis, while China has only increased its financial power. As a result, China's influence could increase considerably in South America, especially in Brazil. Another sign that can be seen as negative in the Sino-Russian relationship is the fact that China refused to recognize Abkhazia and South Ossetia as in-

43 Maria Belova, "The Oriental Vector," Oil of Russia 2 (2009); available at www.oilru.com/or/ 39/793/.

44 Vladimir Socor, "Strategic Implications of the Central Asia-China Gas Pipeline," Eurasia Daily Monitor 6:233 (18 December 2009).

45 Ibid.

46 Stephen Blank, "La Russie et l'Amérique Latine: Manoeuvres Géopolitiques dans le Voisinage des Etats-Unis," IFRI, Russie.Nei.Visions 38 (April 2009). 
dependent, which is a clear message of disapproval of Russia's military intervention in Georgia.

Fifth, as China is developing its economy and has easily weathered the international crisis, it still remains the most important buyer of Russian arms and military technology. China is currently displaying all the signs of wanting to be a major actor in international relations, which may cause Russia to worry about China's ambition to become a major global power as well as a possible competitor. The Russian Far East has long been under-developed and deindustrialized. China may provide development to this part of Russia through two main areas: its supply of qualified workers, and the financial support that would follow their emigration. In 2004, in the region on the Russian side of the border in the Far East there were seven million inhabitants; in the region on the Chinese side, there were more than one hundred million. Chinese migrants started to move to the Russian Far East in 1992, and the number of Chinese emigrants has considerably increased since then. The Russian authorities put the number of emigrants at a maximum of several thousand, although there are certainly several million Chinese working in the region, according to unofficial sources. ${ }^{47}$ Today, the demographic imbalance is even more severe, since 110 million people live in northeast China, while the Russian population in the Far East decreased to 6.6 million and is expected to drop to 4.5 million people in $2015 .^{48}$

Oil and gas development - particularly in the Far East region, where it will require huge investments and the use of modern technologies - might not have any positive impact on the Russian labor market, since it will require highly qualified and available workers, which only China can provide. In addition, Chinese workers are paid around USD 100 a month, which is half the average Russian salary, and hence makes hiring Chinese workers more appealing to Russian businessmen, although it creates resentment among the Russian population. To paint a bleaker picture of the situation, local governments and businesses are often accused of corruption, and have formed connections with Chinese organized crime. ${ }^{49}$

In February 2009, an incident occurred in Russian territorial waters between a Russian border guard craft and Chinese-owned vessel near the port of Vladivostok. This may be one piece of evidence of the broader deterioration of the relationship between the two countries. ${ }^{50}$ The concerns in Russia are not only over immigration and weak responses from the government, but also about the military balance related to Russian exports to China. China not only imports state-of-the-art military equipment and technology from Russia; it has also developed its own military-industrial capability. China might, in the long term, compete with Russia in high-tech arms sales on the global

47 Yevgeny Bendersky, "Russia-China Relationship Favors Beijing," Asia Times Online (12 August 2004); available at http://atimes01.atimes.com/atimes/Central_Asia/FH12Ag01.html.

48 "Tensions with China in Russia's Far East Fueled by Demographics, Quest for Resources," WorldTribune.com (6 March 2009); available at www.worldtribune.com/worldtribune/

49 WTARC/2009/ea_china0195_03_06.asp.

50 Ibid. 
market. Besides, China makes no effort to hide its strategic ambition to project its power, and hence its willingness to create a powerful People's Liberation Navy relies mainly on two components: a surface fleet (mainly equipped with destroyers) and nuclear submarines. In its 2006 Defense White Paper, China envisaged reaching relative parity with the Japanese Navy in 2010, and between 2010 and 2020 the PRC hopes to be able to intervene militarily to the "Blue Line." 51 Between 2020 and 2050, China wants to impose itself as a naval power in East Asia, and thus to intervene beyond the "Blue Line." 52 Russia will probably be excluded from the geostrategic chess game being played by the United States and China, and the strategic energy partnership should suffer from this exclusion. Another fact demonstrates that Russia is more careful with China than ever. In 2009, Russia leased its nuclear submarine Akula II to India instead of China, first because India appears to be a more trusted partner, second because Russia wants to safeguard its advanced technology, and third because Russia suspects China of selling military equipment behind its back.

The last obstacle to a strong Sino-Russian strategic energy partnership is the fact that Russia has been trying to find new energy partners in Asia, and has forged tighter relationships mainly with Japan and South Korea. In February 2009, Japan and Russia inaugurated the liquefied natural gas plant at Sakhalin II. Thus Osaka Gas will be provided with 200,000 tons of LNG on a yearly basis for the next twenty years. The completion of the project shows that Russia and Japan are able to cooperate for the best, despite the ongoing dispute over the Kuril Islands. It also shows that Russia is not solely a dependent partner of China in the Asian energy market. South Korea will also benefit from Sakhalin II, since it will allow South Korea to get Russian gas at a lower price than it has been paying for gas from the Middle East. ${ }^{53}$ Furthermore, in May 2009, construction began on the Sakhalin-Khabarovsk-Vladivostok gas pipeline. A memorandum of understanding was signed in July 2009 between Gazprom and South Korea's Korea Gas Group in order to examine the possibility of extending the SKV gas pipeline to South Korea. Two routes would be possible: one bypassing North Korea (which would be risky) and one direct undersea route (which would be very expensive) ${ }^{54}$ The first phase of the ESPO pipeline, which was launched by Russian Prime Minister Vladimir Putin in December 2009, will transport oil from Russia's western and central oil fields to the Pacific Ocean in order to be exported to Japan, a project that is partly financed by Tokyo. ${ }^{55}$

51 The Blue Line is a line going from the Kuril Islands, passing by the Mariana Islands to reach Papua New Guinea.

52 E. Franco, "La Chine Renfloue sa Marine pour Asseoir ses Ambitions Régionales," Armées d'aujourd'hui 320 (May 2007): 14.

53 Stephen Blank, "Sakhalin's LNG Plant and Its Implications," Pipeline and Gas Journal 236:4 (April 2009).

54 Eric Watkins, "Gazprom, Kogas Sign MOU for Sakhalin-2 Pipeline Project," Oil and Gas Journal 107:26 (13 July 2009): 33.

55 "Russian Prime Minister Putin Launches the ESPO Pipeline," Green Car Congress (30 December 2009); available at www.greencarcongress.com/2009/12/espo.html. 


\section{Conclusion}

Although China and Russia have been developing a strong energy partnership, the interests of these two countries will inevitably differ. The partnership may appear to be strategic for Russia, because of the necessity for Russia to diversify its exports. More importantly, Russia needs massive Chinese investments in its energy sector. European investors are more reluctant to invest in a country like Russia, whose political instability makes external financial projects risky. Nevertheless, these investments are vital for Russia's economy and budget. China, on the other hand, has shown its willingness to invest in the oil and gas sectors, principally in the eastern part of Russia. However, in spite of friendly official cooperative declarations, China does not want this partnership to be strategic, especially outside the corridors of private bilateral conferences. There is a real divergence between the rhetoric and the reality.

Russian and Chinese views of the structure of the world system itself differ. The Russians miss the grand strategy approach; the Cold War model no longer exists, and the Russians seem to regret this epoch's passing. A "new G3" is being built, made up of the U.S., China, and the EU. For the Americans, the Russians are now second-string players. Moreover, an emphasis has been recently placed on the creation of different "G2s" between the U.S. and the EU, the U.S. and Japan, the U.S. and China. All these structures exclude Russia, to Russia's dismay. ${ }^{56}$

China is anxious to play a major role in the international chess game, and it has no intention of giving Russia the opportunity to use oil and gas as leverage against the Chinese government. In its past approach to European countries, Russia has tried to use oil and gas as an instrument of its foreign policy. China is striving to diversify its imports, investing in several different, geographically dispersed countries, and is enhancing its relationships with oil and gas producers all around the world. This diversification policy and China's thirst for oil and gas may create friction, and even possible conflicts in the future. This is especially true in the South China Sea, where China claims sovereignty over several disputed areas that are rich in natural resources. From this point of view, China might be seen as more aggressive in Asia, especially in South East Asia.

Furthermore, China aims to buy oil and gas at low prices, whereas Russia naturally is trying to sell its natural resources at the highest prices. Negotiations about further Sino-Russian cooperation on gas have been blocked for three years because of this issue. The disagreement about the price China should pay for Russian gas should be resolved in 2010, but this is subject to further consultations. Above all, China will refuse to pay for gas at the price Europeans are already paying. However, according to the International Energy Agency, in 2020 the share of gas in China's overall energy con-

56 During a seminar organized by the GCSP on 25 February 2010, Professor Lanxin Xiang said that in the short term he had an optimistic view of the Sino-Russian strategic partnership. But, in the long term, his view is more pessimistic, since the exclusion of Russia from the grand geostrategic game might provoke the issue of Russian identity. 
sumption will grow to at least 10 percent, and China will not have any other viable solution to fill this demand.

For China, the time for decisions has come. Reducing its domestic consumption is impossible, while slowing down the increase in consumption is still possible. Improving its partnerships with major energy producers like Iran may prove vital to Beijing. China will have to develop green technology, and this revolution must be supported at the outset by the Chinese authorities. If Russia's role as an oil and gas provider for China increases, China will strive to limit its dependency, employing all the methods at its disposal.

Finally, the so-called strategic partnership seems to be doomed. The gap will grow between the official speeches and the changing reality. In 2020, China will be the top economic power in the world. Its political system is not likely to change, as long as it continues to provide stability and improving standards of living to the Chinese population. In 2050, China will be able to make use of its full set of tools, which will include a formidable military capacity of projection. This statement is not true for Russia. Its stagnant economy, based almost entirely on arms sales and natural resources, will have to be reformed profoundly. In addition, the government's role in the private sector will also have to be redefined. The strategic energy partnership with China is geologically limited, and is not compensated for in other sectors. Russia's arms sales will decrease as China develops its own production. All factors indicate that the global trade balance between the two countries will be in favor of China. In the end, nothing will be strategic in the Sino-Russian partnership any longer, and Russia may turn towards Europe to rekindle strategic relations with a closer partner. 


\section{Bibliography}

Belova, Maria. "The Oriental Vector." Oil of Russia 2 (2009).

Bendersky, Yevgeny. Russia-China Relationship Favors Beijing. Asia Times Online, 2004.

Blagov, Sergei. "Russia Resumes Electricity Exports to China." Eurasia Daily Monitor 6 , no. 65 (2009).

Blagov, Sergei. "Russia's Gas Pipeline Network Faces Reality Check." Eurasia Daily Monitor 4, no. 150 (2007).

Blank, Stephen. "La Russie et l'Amérique Latine: Manoeuvres Géopolitiques dans le Voisinage des Etats-Unis." IFRI, Russie.Nei.Visions 38 (2009).

Blank, Stephen. "Sakhalin's LNG Plant and Its Implications." Pipeline and Gas Journal 236, no. 4 (2009).

BP Statistical Review of World Energy., 2009.

Burgansky, Alex. Russian Oil and Gas Industry Surprises Analysts. Seeking Alpha, 2009.

China, Russia End Lengthy Border Dispute. Moscow News 41 (2008).

China: Coal. U.S. Energy Information Administration, 2009.

China: Natural Gas. U.S. Energy Information Administration, 2009.

China: Oil. U.S. Energy Information Administration, 2009.

Country Analysis Brief: China. U.S. Energy Information Administration, 2009.

EU-Russia Energy Dialogue. European Commission Energy Website, 2009.

Franco, E.. "La Chine Renfloue sa Marine pour Asseoir ses Ambitions Régionales." Armées d'aujourd'hui 320 (2007): 14.

Guillemoles, Alain. "Gazprom, a Giant for the Benefit of Kremlin." Politique Internationale 116 (2007).

Higashi, Nobuyuki. Natural Gas in China: Market Evolution and Strategy International Energy Agency In Working Paper., 2009.

Korzhubayev, Andrey. "Hydrocarbon Arteries of Russia." Oil of Russia (2009): 2.

Lo, Bobo. Axis of Convenience: Moscow, Beijing, and the New Geopolitics. Washington, D.C.: Brookings Institution Press, 2008.

Locatelli, Catherine, and Jean-Pierre Angelier. What Development for Gas in China. Laboratoire d'économie de la production et de l'intégration internationale, 2007. 
Margeson, John. Russia: Survey of Russian Energy Infrastructure. International Analyst Network, 2008.

Mazneva, Elena. "Neft na 20 let vpered." Vedomosti 29 (2299) (2009).

Panizzo, Alexandre. "China’s Oil Thirst." Le Figaro (2008).

Power Reactor Information System. International Atomic Energy Agency, 2010.

Qiang, Guo. Russia, China Cement Oil Cooperation. Chinadaily.com.cn, 2006.

Randrianarimanana, Philippe. "Good Weather on Economic Cooperation." Courrier International (2009).

Russia Independent Statistics and Analysis. U.S: Energy Information Administration, 2008.

Russia Natural Gas. U.S. Energy Information Administration, 2008.

Russia, China Agree on West Siberia, Far East Gas Supplies. RIA Novosti, 2009.

Russian Prime Minister Putin Launches the ESPO Pipeline. Green Car Congress, 2009.

Socor, Vladimir. "Strategic Implications of the Central Asia-China Gas Pipeline." Eurasia Daily Monitor 6, no. 233 (2009).

Tensions with China in Russia's Far East Fueled by Demographics, Quest for Resources. WorldTribune.com, 2009.

The EU and Russia Reinforce the Early Warning Mechanism to Improve Prevention and Management in Case of an Energy Crisis. European Commission Energy Website, 2009.

Verluise, Pierre. How the EU Reinforces Russia’s Power. diploweb.com, 2006.

Vidalenc, Sabrina. Russian Far East: A New Frontier?., 2009.

Watkins, Eric. "Gazprom, Kogas Sign MOU for Sakhalin-2 Pipeline Project." Oil and Gas Journal 107, no. 26 (2009): 33.

Woehrel, Steven. Russian Energy Policy toward Neighboring Countries. Washington, D.C.: Congressional Research Service, 2009. 